\title{
Fate of the Product Mix of a Firm with a Mandate to Adopt a Food Quality Metasystem: The Case of Adoption of the SLS in the Fruit Processing Sector in Sri Lanka
}

\author{
S. Rajapakse and U.K. Jayasinghe-Mudalige *
}

\begin{abstract}
This study assesses the impact of a number of characteristics pertaining to fruit processing firms in the Western Province in Sri Lanka to adopt the Sri Lankan Standards (SLS). It hypothesized that in the presence of a "mandatory" government regulation to adopt the SLS on the firm, the decision of the management to "invest" on it without removing any of their major products in the product mix or to exercise a "product exit" (i.e. removing a major product) will depend on factors such as the type of ownership, recent modifications made to the facility by introducing modern processing technologies, other enhanced food safety controls in place, whether the firm is involved with international markets, availability of skilled labour, and annual returns of the firm (adjusted to the number of employees and major products). The primary data collected through a series of in-depth personnel interviews with quality assurance managers and site visits to 36 firms during May to July 2005 were analyzed using Logit Regression technique. The results suggest that firms that modify their facilities, hire skilled labour, promote exports, and possess other advanced food safety controls have a tendency to adopt the SLS without a partial exit. The outcome of the analysis elaborates that policy makers must take into account the business environment of the firm implicitly and explicitly in their attempts to adopt the mandate for the implementation of enhanced food safety controls like the SLS on agri-food processing enterprises.
\end{abstract}

The authors are, respectively, Graduate Student and Senior Lecturer in the Department of Agribusiness Management, Wayamba University of Sri Lanka. 


\section{Introduction}

\section{Role of Regulation on Food Processing Firms}

Regulation has become a major element of the environment in which firms operate that constrain their strategic behaviour. The food industry is one example of this. Marcus (1984) reports three main strategic choices faced by a firm, in general, in it's response to regulation: (a) stonewalling - where the firm attempts to ignore or ride out the problems created by the regulation; (b) opportunity seeking - where the firm sees the regulation as an opportunity to gain competitive or other advantages and; (c) a mixed strategy - where new product development and heavy marketing might characterize firm's response - may be in a new area for the firm.

Firms that adapt quickly to new more stringent regulations gain a type of 'first mover' advantage in the market place, which helps it to compete with others in the industry as these regulations become more widely adopted (Porter and Linde, 1995). According to Rugman and Verbeke (1998), cooperate response of firms to be in compliance with regulation depends on the expected economic benefits. They suggest that a firm may choose to comply voluntarily to regulation if it is triggered by "market-based incentives" such as first mover advantage. However, in many cases, compliance with regulation depends on the strength of the enforcement authorities, i.e. "regulatory incentives". In the case of the food processing sector, Henson and Heasman (1999) show that enforcement could play a very different role in the regulatory process for assuring safety of food.

French and Neighbors (1991) identified a number of regulatory variables affecting the nature of a firm's reaction to public food safety regulation. First, the scope of the regulation determines the products, firms, and industries affected. Some regulations are quite limited in scope (e.g. a warning statement on a product label about possible negative effects on health), whilst certain others can be extensive (e.g. banning of an essential ingredient or mandatory certified training for all food handlers). Second, the significance of the regulation refers to its expected impact on consumers' perceptions of a product. Firms may reformulate products or even discontinue them ("partial exit") if the regulatory change put the product in a particularly bad light. Third, the complexity of the regulatory change has a big impact on a firm's strategic responses with more complex changes involving a 
coordinated response between several functional areas of the firm. Finally, the length of the compliance period determines the type of response a firm makes and the compliance costs it incurs. For legislative changes that involve complete overhaul of production processes or review of management processes, a more lengthy compliance period may be required for a firm to gain the knowledge and expertise to implement new regulations.

Certain regulations and modern trading conditions have required food businesses to demonstrate their commitment to food quality by establishing an appropriate program to assure product quality and safety (Unnevehr and Jenson, 1999). Such a program should take into account the role of business in the food chain in particular, i.e. whether they are primary producers, manufacturers, retailers or caterers. The food quality management metasystems such as Hazard Analysis and Critical Control Points (HACCP) and ISO 22,000 introduced to the food industry should therefore be concerned with four primary elements: (a) meet the expectations of consumers; (b) fit within the strategy of the company; (c) ensure that a company is clearly committed to the safety and quality of its products; and (d) aim for the highest level of safety and quality achievable in terms of effectiveness and efficiency.

Several other economists have attempted to develop models of firm's compliance decisions to government regulation in a more general perspective (Cole and Sommers, 1981; Baron and Baron, 1980). There were some models that were developed to explore the impact of food safety legislation on food processing firms operating in developed countries (Caswell and Johnson, 1991; Henson and Heasman, 1999; Loader and Hobbs, 1999). However, the interrelationship between the regulatory activities of government and the strategic behaviour of firms is not well recognized in the food economics literature in the context of food processing sectors in developing countries.

\section{Food Quality Assurance and the SLS}

Adoption of a food quality assurance system has become an integral part of the major activities associated with a firm. The food economics literature uses a number of different classifications to identify the types of food quality metasystems. Caswell et al., (1998), for example grouped those metasystems into three basic categories, including: (1) those "mandated" by governments through regulatory requirements; (2) those adopted "voluntarily" by companies, and (3) "quasi-voluntary" - those required by such a large 
proportion of the market as to become de facto required standards operating procedure. Albeit with differing origins, most of these systems share several common features, including: (a) certification audit - they require a periodic verification by an unbiased third party that certifies the company is in compliance with the metasystem; (b) documentation of practices -"write what you do, and do what you wrote", and (c) implementation and approval (Holleran et al., 1999).

The increasing application of such systems reflects the economic and social incentives faced by individual businesses that operate within the food supply chain. Certain of these incentives may be common to all firms operating in a particular sector, for example regulatory developments, whereas others may be business-specific, for example the requirements of major customers (Henson and Hooker, 2001). The dynamics of metasystem adoption depend on, according to Caswell et al., (1998), the internal benefits and costs of adoption to companies, risk management goals, competitive advantage that may be gained or maintained in domestic and foreign markets, and possible gains in system efficiency. Thus, in addition to affecting operation of the value chain, food quality metasystems are likely to confer significant marketing advantages on companies in selling to final consumers.

In the context of Sri Lanka, the Sri Lanka Standard Institution (SLSI) Act No. 6 of 1984 empowers the SLSI to issue permits to manufacturers for the use of the SLS mark in respect of those commodities that conform to the relevant Sri Lankan Standards. Primary purpose of this scheme is to convey to the purchaser a guarantee that the goods have been tested and certified by a third party independent government institution and that these may therefore be purchased with a reasonable assurance of quality.

Manufacturers equipped with the requisite production and testing facilities to carry out basic essential tests could apply to the SLSI on the prescribed form in duplicate with the required application fee to obtain the SLS, where a separate application should be made for each commodity covered by the particular standard. On receipt of an application, the institution will arrange a preliminary inspection of the factory to examine the testing facilities available with the applicant and the manner in which a Quality Management System (QMS) is being implemented and to ensure that the technical demands of the quality of products called for by the institution measure up to the SLS. The manufacturers are required to develop their QMS 
in line with twelve elements prescribed in the "SLS" marking scheme introduced by the SLSI (Directory of Certified Products, 2003).

The SLSI will in turn appoint a well qualified audit team to carry out an independent audit with respect to the implementation of QMS and the capability of manufacturers in producing the commodities conforming to the standard and report to the Permit Committee on the SLS Product Certification Activities and their recommendations. The Permit Committee will study these recommendations and the license to use the SLS mark will be issued for a 3year period, if satisfactory. Once the license has been granted, the manufacturer shall display the SLS symbol on the product (Table 1).

Table 1: $\quad$ The SLS certified product types.

\begin{tabular}{lc}
\hline \multicolumn{1}{c}{ Product Category } & No of Certified Brands \\
\hline Based on Type of Commodity & 93 \\
Food Products & 50 \\
Building Materials & 31 \\
Electrical Products & 9 \\
Soap Powder and Colognes & 6 \\
Rubber Products & 4 \\
Textile Products & \\
On Specific Food Products & 18 \\
Ready - to - Serve Fruit drinks & 12 \\
Fruit Syrups, Squashes and & \\
Cordials & 8 \\
Jams and Marmalades & 2 \\
Fruit Squash Concentrates & 2 \\
Jelly Crystals & 1 \\
Tomato Sauce & \\
\hline
\end{tabular}

Source: Directory of Certified Products of the Sri Lankan Standard Institution, 2003

As per the directions issued by the Commissioner of Internal Trade under section 6.1(c) of the Consumer Protection Act No. 1 of 1979, now there is a regulation that no manufacturer or trader sell, offer for sale, or expose for sale any locally manufactured or locally produced processed food products, such as "ready-to-serve" fruit drinks (SLS 729:1985), fresh fruit cordials (SLS 214:1985), fruit cordial and syrup concentrates (SLS 730:1985) and synthetic 
cordial (SLS 221:1985), unless such article bears the SLS mark (Directory of Certified Products, 2003).

\section{The Economic Problem}

In regulating the businesses by way of public legislation, according to Stigler (1971), governments force them to operate within certain constraints when the social costs of private market activity are considered great and government action is needed to mitigate a market defect. According to Peltzman (1976), firms may attempt to co-options the regulatory process in an attempt to gain strategic advantage. This can occur at the level of the individual firm or the industry through, for example, interest groups.

In the context of the fruit processing sector in Sri Lanka, an individual firm operating in this sector may face different lines of problems with regard to its decision to adopt the SLS. By adopting the SLS, on the one hand, post implementation issues like difficulty of covering the SLS compliance costs may be faced if it does not create significant increase of sales to cover such costs. If a firm decides not to adopt the SLS in the presence of mandatory requirement to implement it, management of the firm will have to face the repercussions imposed by the public regulatory bodies, for example temporary or permanent closure of the plant. Along with that, the affected firm might face a "market test" in terms of pressure from their major customers to abide to high food quality standards so as to remain as a client. Also, there may be certain restrictions imposed by relevant authorities that prevent exporting their products etc. These potential direct and/or indirect "costs" to the firm that are associated with adoption of a QMS may lead a firm to "exit wholly from the industry" (i.e. plant-exit) or remain in the industry by "dropping those affected products from the product mix"1 (i.e. partial exit).

In the presence of mandatory government regulation to adopt the SLS for a large number of generic food products (eg.. jam, cordials, chutney, sauce etc.) that may be produced using the same production line simultaneously, a food processing firm will have to decide whether to comply or not to comply with the standards. However, if it decides not to comply, a firm will be

${ }^{1}$ The "product mix" refers to the number of products the firm in question produces at a given period of time. 
"asked" subsequently to obey the government regulation, and in turn to exercise a product or plant ext. The economics associated with a firm's decision to exit, fully or partially, under these circumstances have been examined empirically to some extent from the developed country perspective. Hooker et al. (2002), for example, examine this problem in the context of meat processing firms operating in Texas in the United States of America. They insisted that restructuring to the facility and staff, the required starting date of implementation, and final date of compliance to the "HACCP-rule" of the United States Department of Agriculture (USDA) have largely influenced small and very small meat processing firms' exiting their major products. Although very small firms incurred higher compliance costs than small plants, there was no evidence to show whether the former, in general, undergo higher levels of product exits Antle (1996) reports that compliance to the mandatory HACCP regulation in the United States involves significant start-up costs that are independent of size of operation and, as a result, the form of regulation may threaten economic survival of smaller firms. Anderson and Leel (2001) and MacDonald et al., (1996) also suggest that, from the various countries perspective, the rate of survival of small-scale food processing enterprises in the presence of mandatory HACCP regulation is critical. However, there are limited studies carried out from the developing country perspective on this particular issue, and there is a paucity of literature that used data from the food-processing sector in Sri Lanka.

\section{Methods}

This section presents the empirical model used to examine the economic problem of this study, and the measures used to collect and analyze data.

\section{Empirical Model}

It was hypothesized that in the presence of a "mandatory" government regulation to adopt an enhanced food safety control system such as the SLS, the management of a firm has two options $\left(D_{i}\right)$ :

1. The firm can invest it's scarce resources (with high opportunity cost) on the adoption of the food safety and quality assurance system mandated, or

2. It can exercise a product-exit or a plant-exit. 
Consequently, both the human and socio-economic characteristics pertaining to the management of a firm $\left(I_{i}\right)$ (e.g. age, level of education, and risk tolerability etc.) and the characteristics of a firm $\left(F_{i}\right)$ (eg. size of the firm, its overall profitability, whether it already possesses a quality assurance system in place that is equivalent to the one mandated by the government, and whether it has to modify the current facility with modern technologies to accommodate the new system etc.) will have a greater impact on the decision of a firm, both implicitly and explicitly, to adopt or not the quality assurance system mandated (in this case, the SLS) (Caswell et al., 1998).

In fact, in a situation like this, one can suggest that the influence of certain characteristics associated with the firm (e.g. firm size, profitability) on this decision can be greater than that caused by "human characteristics" of the management (i.e. age, level of education). Henson and Heasman (1999), for example, stated that firm size as one of the most important factors that describes the differences in the manner in which individual businesses comply with new regulation, especially with respect to a firm's decision-making behaviour at different stages of the compliance process. According to Loader and Hobbs (1999), a small firm with low market power complies with new regulation at a later stage in the compliance process and is more likely to choose limited or non-compliance as a strategic reaction to such regulatory requirements compared to a large firm. Considering all the above, a firm's decision to "invest" or "exit" $\left(D_{i}\right)$ can be expressed using the Equation (1) below, where $\varepsilon_{\mathrm{i}}$ stand for the random error term:

$$
D_{i}=f\left(I_{i}, F_{i}\right)+\varepsilon_{i}
$$

Using the Equation (1), the following empirical model can be derived to explore the major "firm characteristics" that will have an impact on firm's behaviour, where the terms $\beta_{0}$ and $\beta_{j}$ stand for the intercept and coefficients of the explanatory variables $(j=1,2 \ldots m)$, respectively:

$$
\begin{gathered}
D_{i}=\beta_{0}+\beta_{1} . O W N E R+\beta_{2} \cdot M O D_{-} F A C+\beta_{3} \cdot O T H+F S C+ \\
\beta_{4} . \text { EXPORT }+\beta_{5} . S K L_{-} L B R+\beta_{6} . P E R_{-} I D X+\varepsilon_{i}
\end{gathered}
$$


The dependent variable $D_{i}$ is a binary variable. Therefore, $D_{i}=1$ if the firm in question $(i)$ possesses the SLS for all of its major products ${ }^{2}$ in the product mix. On the other hand, $D_{i}=0$ if it "discontinues" one or more than one of its major products from the production cycle since it has no ability to adopt the recommended standards for that particular product/s (i.e. productexit) or totally exit ${ }^{3}$ from the industry (i.e. plant-exit) due to the same reason. The descriptions of explanatory variables used in the model are reported in Table 2 .

The variable $O W N E R$ symbolizes type of ownership of the firm. Henriques and Sadorskey (1996), from the Canadian environmental firms context show that a firm managed by a single owner or as a family business was reluctant to administer an Environmental Management System (EMS) compared to a firm that is managed as a partnership/joint venture. It was hypothesized that this phenomenon was true in the case of adoption of a Quality Management System like the SLS. Consequently, tendency of a firm to exercise a product or a plant exit is higher when it is managed by a single owner or as a family business. Further, it was hypothesized that a firm that was modified recently (i.e. after January 2002) by implementing modern food processing technologies $\left(M O D \_F A C\right)$ was in a better position to adopt the SLS without exiting a product compared to a firm that possesses a rather conventional/outdated production technology.

A firm that possesses a QMS that is analogous to the SLS $\left(O T H \_F S C\right)$, employed skilled labor to handle quality related work who were handpicked for the purpose $\left(S K L \_L B R\right)$ and exporting to an other country directly and/or through another firm in the supply chain (EXPORT) also tend to adopt the SLS for all of its major products than a firm that did not possesses these characteristics. Together with these, the "financial status" of a firm and its "relative position in the market" will have a greater impact on its decision to adopt a quality assurance system (Antle, 1996). The influence of

${ }^{2}$ For the purpose of this analysis, any product is considered to be a "major product" of a firm, if it is responsible for at least $25 \%$ of the total sales income of that firm. For this reason, there may be up to four major products for a given firm (theoretically) each with $25 \%$ of sales income.

${ }^{3}$ In this scenario, a firm will have to remove all of its "major products" from the production cycle that requires the SLS. However, it may not be totally going out of business, because firm has an opportunity to move into production of certain other product/s that does not need the SLS certification. 
both of these factors has been explored by means of an index (PER_IDX) by taking into account difficulties associated with collecting of such data (e.g. confidentiality and sensitivity of information to the competitors) (Table 2).

Table 2: $\quad$ Explanatory variables used in the model

\begin{tabular}{|c|c|}
\hline Variables & Description \\
\hline OWNER & $\begin{array}{l}\text { Type of ownership }=(\text { partnership with agreement } / \text { limited } \\
\text { corporation } / \text { otherwise }=1 \text {; single owner } / \text { family business }= \\
0)\end{array}$ \\
\hline \multirow[t]{2}{*}{$M O D \_F A C$} & $\begin{array}{l}\text { The current facility has been modified within the last three } \\
\text { years (after January 2002) by introducing modern processing } \\
\text { technologies, where the cost was more than } 30 \% \text { of the } \\
\text { firm's sales revenue of that year }\end{array}$ \\
\hline & $(\mathrm{Yes}=1 ; \mathrm{No}=0)$ \\
\hline \multirow[t]{2}{*}{ OTH_FSC } & $\begin{array}{l}\text { Availability of other food safety controls in place that is } \\
\text { audited at least once a year by a third party agency (e.g. } \\
\text { HACCP, ISO 9000, Certified GMP) }\end{array}$ \\
\hline & $(\mathrm{Yes}=1 ; \mathrm{No}=0)$ \\
\hline EXPORT & Exporting to international markets $(\mathrm{Yes}=1 ; \mathrm{No}=0)$ \\
\hline$S K L \_L B R$ & $\begin{array}{l}\text { Hiring of new and skilled labour to carry out the specialized } \\
\text { activities such as record keeping, tracing and monitoring } \\
\text { (more than } 10 \% \text { to the existing cadre }=1 \text {; no hired labor or } \\
\text { less than } 10 \% \text { of the existing cadre }=0 \text { ) }\end{array}$ \\
\hline$P E R \_I D X$ & $\begin{array}{l}\text { Performance Index }=\text { (Annual turnover of the firm / Average } \\
\text { annual turnover of the sample) / [(Number of employees of } \\
\text { the firm / Average number of employees in the sample) } * \\
\text { (Number of major products of the firm / Average number of } \\
\text { major products of the sample)] }\end{array}$ \\
\hline
\end{tabular}

\section{Data Collection and Analysis}

The Register maintained by the Department of Census and Statistics in Sri Lanka contains the names of 71 fruit processing firms located in the Western Province in Sri Lanka (Table 3). These were selected as the cases for 
collecting data, since a firm in this sector faces the threat of having a system of SLS in place or to remove that product from the product mix.

Table 3: Number of fruit processing firms in the Western Province in Sri Lanka

\begin{tabular}{|c|c|c|c|c|c|c|}
\hline \multirow[t]{2}{*}{ District } & \multicolumn{2}{|c|}{$\begin{array}{c}\text { Medium \& Large } \\
\text { Firms } \\
(\text { Employs }>\text { 10) }\end{array}$} & \multicolumn{2}{|c|}{$\begin{array}{c}\text { Small Firms } \\
(\text { Employs }<10)\end{array}$} & \multicolumn{2}{|c|}{ Total } \\
\hline & Number & Employees & Number & Employees & Number & Employees \\
\hline Colombo & 9 & 483 & 16 & 61 & 25 & 544 \\
\hline Gampaha & 6 & 575 & 28 & 84 & 34 & 659 \\
\hline Kalutara & 3 & 61 & 9 & 17 & 12 & 78 \\
\hline TOTAL & 18 & 1119 & 53 & 162 & 71 & 1281 \\
\hline
\end{tabular}

First, a series of telephone calls were made to the quality assurance managers and/or owners of these firms in April 2005 to get their consent to collect data for the analysis. During this conversation, it was indicated that the research team wanted to visit the firm to examine the "technology" it uses, and information pertaining to the human resources of the firm (both labourers and management), as well as its relative position in the market (i.e. financial and sales).

There were 54 respondents $(76 \%)$ to these telephone calls who expressed their desire to give an opportunity for a visit, however, subject to various constraints. Amongst these 54 firms, however, the entrepreneurs /management of only 36 firms participated in the survey characterized by an in-depth personnel interview and site inspection carried out from May to July 2005. The other 18 firms that expressed their desire to participate earlier, however, indicated that they did not want to participate in the study indicating various reasons ${ }^{4}$.

${ }^{4}$ Although every effort was made to get the consent of the management of 35 out of 71 firms in the sample that refused to participate in the study, it was not successful since they considered some information were "highly confidential" and "sensitive to their competitors". 
The interviews were supported by a semi-structured questionnaire, which was pre-tested using on-site visits to three fruit processing firms. At the end of coding of data, there were three firms with more than 100 employees and more than Rs. 10 million annual turnover excluded from the sample as they were considered "extreme outliers" as compared to others in the sample. Amongst the 33 firms remaining in the sample ${ }^{5}$, there were 20 firms (i.e. about $60 \%$ ) with employees less than 10. By taking into account the dichotomous nature of the dependent variable, the Logit Regression technique (Pampel, 2000; Borooach, 2002) were used to estimate the coefficients of variables included in the empirical model.

\section{Results and Discussion}

\section{Descriptive Statistics}

The average, minimum and maximum values estimated for a number of characteristics of firms included in the sample are reported in Table 4. It shows that there was a large variation amongst the firms with respect to these characteristics. For example, the value of aggregate annual sales of the smallest $50 \%$ of firms in the sample (i.e. $\mathrm{N}=17$ ) was Rs. $1,732,615$, whilst that of the largest $50 \%$ of firms was Rs. 27,627,976 (i.e. about 16 times higher than the smaller category).

Table 4: $\quad$ Descriptive statistics of the sample

\begin{tabular}{llccc}
\hline Characteristic & \multicolumn{1}{c}{ Unit } & Average & Minimum & Maximum \\
\hline Age of the Firm & Years & 8.8 & 0.9 & 37 \\
Employees & Persons & 23 & 2 & 150 \\
Product Mix & Number & 2.5 & 1 & 7 \\
Annual Sales & Rs. ('000) & 333.7 & 18.7 & 7488 \\
\hline
\end{tabular}

Source: Directory of Certified Products of the Sri Lankan Standard Institution, 2003.

${ }^{5}$ The inferential statistics that used data from 33 firms can be considered valid and reliable, and representative of the total population in the Western Province, since it satisfies the properties of a large sample, including "unbiasedness" and "consistency" (Pampel, 2000). 
The Mean values of the explanatory variables are reported in Table 5. It shows that about $2 / 3$ of the firms in the sample were managed as a corporation and/or a partnership with an agreement. Nearly $70 \%$ of firms have modified the facility by introducing new equipment. However, less than $50 \%$ of these firms have hired a full-time skilled labor force after January 2002 to operate this equipment and to manage other related activities. In fact, many firms have provided short induction training to the existing work force on the use of these tools and machines for food processing that used materials available from various sources, including the SLSI instead of hiring new and qualified persons to carry out food safety and quality related work. The firms involved with exporting of their products were relatively low (i.e. 27\%). There were less than $10 \%$ of firms adopting HACCP, ISO 9000 types of food safety metasystems and/or Good Manufacturing Practices (GMP) with regular record keeping.

The results suggest that about $70 \%$ of firms that have responded to the survey effectively (i.e. $23 / 33 * 100$ ) have already removed at least one of its major products (i.e. partial-exit) in its process of adopting the SLS. Consequently, all these firms, at least in the short run, have lost a minimum $25 \%$ of their sales revenue once the SLS was implemented. About $30 \%$ of these firms were managed by a single owner or as a family business. There were about $39.4 \%$ and $27.2 \%$ firms that exercised a product-exit and were managed by a single person or a family and as a partnership with agreement or corporation, respectively, who have modified their plants to remain in the market with the other major products. For more than $60 \%$ of firms in the sample, the value of the performance index was between 0 and 1 indicating that their performances were, in general, below the industry average of the Western Province. Further, there were about $75 \%$ and $54 \%$ of firms with the value of performance index falling below and above 1, respectively, who have dropped at least one of their products to remain in the market as mandated by SLS. 
Table 5: $\quad$ Estimates of coefficients from Logit regression analysis

\begin{tabular}{|c|c|c|c|}
\hline Variables & Description & Mean & $\begin{array}{c}\text { Estimate } \\
\text { (Standard } \\
\text { Error) } \\
\end{array}$ \\
\hline OWNER & $\begin{array}{l}\text { Partnership with agreement / } \\
\text { limited corporation etc., but not sole } \\
\text { proprietorship / family business }\end{array}$ & 0.636 & $\begin{array}{c}0.1227 \\
(0.1310)\end{array}$ \\
\hline$M O D \_F A C$ & $\begin{array}{l}\text { Facility has been modified after } \\
2002\end{array}$ & 0.667 & $\begin{array}{l}0.0706^{* * *} \\
(0.0311)\end{array}$ \\
\hline$O T H \_F S C$ & $\begin{array}{l}\text { Other enhanced food safety controls } \\
\text { in place }\end{array}$ & 0.091 & $\begin{array}{l}0.0514 * * \\
(0.0253)\end{array}$ \\
\hline EXPORT & Exporting to international markets & 0.242 & $\begin{array}{l}0.0967 * * \\
(0.0456)\end{array}$ \\
\hline$S K L \_L B R$ & Hiring of new and skill labor & 0.424 & $\begin{array}{l}0.1287 * * * \\
(0.0675)\end{array}$ \\
\hline PER_IDX & Performance Index & 1.589 & $\begin{array}{l}1.1236^{*} \\
(0.0562)\end{array}$ \\
\hline
\end{tabular}

Note: $* * *, * *$, and $*$ denote the significant level of $0.01,0.05$ and 0.10 , respectively

\section{Estimates of Coefficients}

The outcome of the Logistic Regression analysis shows that the model was significant at $5 \%$ probability level. The adjusted R-square of the model was 0.67 indicating that a number of other variables excluded from the analysis, including human characteristics such as age and education level of the management can have a significant impact on a firm's decision to adopt an enhanced food safety control such as the SLS.

Amongst the six independent variables included in the model to describe firm characteristics, there were only two variables, namely $M O D \_F A C$ and $S L K \_L B R$, significant at the probability of 0.01 (Table 5). This suggests that recent improvements to the production facility and hiring of skilled labor to operate these equipment and other related activities were considered to be the most important factors affecting adoption of the SLS in a firm. Two other variables, namely $O T{ }_{-} \_F S C$ and EXPORT were significant at the probability level of 0.05 , and another (i.e. PER_IDX) at 0.10 . This indicates that firms that adopt certain food safety controls of which standards are more or less similar to the SLS and those involved with exporting of their 
products to international markets, in general, have a tendency to adopt the SLS without exercising a product exit. These results were in line with Hooker et al., (2002).

Interestingly, the performance of a firm measured in terms of an index that takes into account annual turnover, number of products and employees in the firm only shows a marginal impact on this decision. Moreover, the management style, i.e. whether it was a family business and/or managed as a single proprietorship and/or a corporation has no significant impact on this behaviour.

\section{Conclusions and Policy Implications}

This study examined empirically the impact of mandating a food safety and quality metasystem (the SLS) on the viability of a firm, i.e. whether it can remain in the market without exiting its major products from the product mix (product-exit) or going out of the market (plant-exit). The results are based on the process of adoption of the SLS in the fruits processing firms located in the Western Province in Sri Lanka.

The results show that a majority of firms had to remove at least one of their major products from the product mix that brought about $25 \%$ decrease of its annual sales in an attempt to comply with the mandatory public regulation. It reveals that a number of firm specific characteristics, including the recent modifications made to the firm and availability of skilled labor to a larger extent and other advanced food safety controls in place, dealing with international markets, and financial status of the firm to some extent have a significant impact on these firms, in general, to remain in the market without exercising a product or plant-exit. All these suggest that those firms that can invest on new equipment and hire skilled labor as needed and possess secured local and international market were in a winning position with the mandatory regulation to implement the SLS.

It provides certain implications to formulate appropriate policy aiming assurance of higher food safety and quality for consumers and securing a profitable and sustainable business environment for food processors. The outcome highlights the importance of giving sufficient time for firms for full compliance with the regulation, especially in the cases where a small firm with a relatively small product mix will have to remove one of its 
major products from the product mix. To avoid creating an unfavorable market environment by these firms, for example "stonewalling" by small firms and "opportunity seeking" by large firms, the regulatory authorities should therefore develop a more market-friendly environment for these firms characterized by provision of accurate information, training and technical support, and low interest credit facilities to improve the facilities to comply with the new regulation.

\section{Acknowledgments}

Authors acknowledge to Dr. K.H. Sarananda (Food Research Unit of the Department of Agriculture), Mr. D.C.A. Gunawardena (The Director Prices and Wages Division of the Department of Census and Statistics), and the managers of fruit processing firms in the Western Province in Sri Lanka.

\section{References}

Anderson, T. and D. Leal (2001). Free Market Environmentalism. Revised Edition. New York: Palgrave.

Antle, J.M. (1996). Efficiency Food Safety Regulation in the Food Manufacturing Sector. American Journal of Agricultural Economics, 78:1242-1247.

Baron, B. and P.B. Baron (1980). A Regulatory Compliance Model. Journal of Contemporary Business, 9:139-150.

Borooach, V.K. (2002). Logit and Probit: Ordered and Multinomial Models. Series: Quantitative Applications in the Social Sciences. No.138.Thousand Oaks: Sage Publication.

Caswell, J.A., and G.V. Johnson. (1991). Firm Strategic Response to Food Safety and Nutrition Regulation. In Economics of Food Safety, J.A. Caswell (ed.). New York: Elsevier.

Caswell, J.A., M.E. Bredahl, and N.H. Hooker (1998). How Quality Management Meta-Systems Are Affecting Food Industry. Review of Agricultural Economics, 20:547-557. 
Cole, R.J. and P. Sommers (1981). Business and Government Regulation: A Theory of Compliance Decisions. Journal of Contemporary Business, 10(1):143-153.

Directory of Certified Products (2003). Sri Lankan Standard Institution, Sri Lanka.

French, M.T. and D.M. Neighbors (1991). A Model of Firm Costs of Compliance with Food Labelling Regulations. In Economics of Food Safety, J. Caswell (ed.). New York: Elsevier. 299-415.

Henriques, I. and P. Sadorsky (1996). The Determinants of an Environmentally Responsive Firm: An Empirical Approach. Journal of Environmental Economics and Management, 30:381-395.

Henson, S. and M. Heasman (1999). Food Safety Regulation and the Firm: Understanding the Process of Compliance. Food Policy, 23:9-23.

Henson, S. and N.H. Hooker (2001). Private Sector Management of Food Safety: Public Regulation and the Role of Private Controls. International Food and Agribusiness, 4:7-17.

Holleran, E., M.E. Bredahl, and L. Zaibet (1999). Private Incentives for Adopting Food Safety and Quality Assurance. Food Policy, 24:669683.

Hooker, N.H., Jr. R.M. Nayga, and J.W. Siebert (2002). The Impact of HACCP on Costs and Product Exit. Journal of Agricultural and Applied Economics, 34(1):165-174.

Loader, R. and J.E. Hobbs (1999). Strategic Responses to Food Safety Legislation. Food Policy, 24:685-706.

MacDonald, J.M., M.E Ollinger, K.E. Nelson and C.R. Handy (1996). Structural Changes in Meat Industries: Implications for Food Safety Regulation. American Journal of Agricultural Economics, 78(August):780-785. 
Marcus, A.E. (1984). The Adversary Economy. London, England: Quorum Books.

Pampel, F.C. (2000). Logistic Regression: A Primer. Series: Quantitative Applications in the Social Sciences. No. 132. Thousands Oaks: Sage Publications.

Peltzman, S. (1976). Towards a More General Theory of Regulation. Journal of Law and Economics, 19:211-240.

Porter, M.E. and C. van der Linde (1995). Towards a New Conception of the Environment-Competitiveness Relationship. Journal of Economic Perspectives, 9(4):97-118.

Rugman, A.M. and A. Verbeke (1998). Corporate Strategies Environmental Regulations. Strategic Management Journal, 19(4):363-375.

Stigler, G. (1971). The Theory of Economic Regulation. Bell Journal of Economics and Management Science, 2:3-21.

Unnevehr, L. and H.H. Jenson (1999). The Economic Implications of Using HACCP as a Food Safety Regulatory Standard. Food Policy, 24:625635 . 